WAYNE VROMAN

Urban Institute

JOHN M. ABOWD

Cornell University

\title{
Disaggregated Wage Developments
}

UNEMPLOYMENT has declined substantially in the United States in recent years, from 9.6 percent of the civilian labor force in 1983 to 5.7 percent in the first quarter of 1988 , while wage and price inflation have remained low. Annual increases in the private nonfarm average hourly earnings index, for example, ranged from 2.0 percent to 3.8 percent and averaged 3.0 percent between 1983 and 1987. During the first three months of 1988 average hourly earnings increased at an annual rate of 2.5 percent.

This report examines nominal wage growth during the 1980s. It first documents the slowdown in wage inflation and then examines possible sources of that slowdown.

\section{Recent Wage Inflation}

Table 1 shows data on average rates of unemployment and of wage and price inflation since 1965. Wage inflation rates for the private nonfarm sector are shown for three series: the hourly earnings index, the employment cost index, and effective wage changes for major union agreements (agreements affecting 1,000 or more workers). Price inflation is shown for the consumer price index and the GNP deflator. In each series, wage and price inflation averaged less than 4 percent a year during 1983-87. Wage growth during that period was at least 5 percentage points below its average during $1980-81$. Not since the early 1960 s has wage growth

The authors acknowledge financial support from the National Science Foundation and the Ford Foundation. Ron Ehrenberg provided helpful comments on an earlier draft. 
Table 1. Average Wage Inflation, Price Inflation, and Unemployment Rates, 1965-87 Percent per year

\begin{tabular}{|c|c|c|c|c|c|c|c|}
\hline \multirow[b]{2}{*}{ Period } & \multicolumn{3}{|c|}{ Wage inflation } & \multicolumn{2}{|c|}{ Price inflation } & \multicolumn{2}{|c|}{$\begin{array}{l}\text { Unemployment } \\
\text { rate }\end{array}$} \\
\hline & $\begin{array}{l}\text { Hourly } \\
\text { earnings } \\
\text { index }^{\mathrm{a}}\end{array}$ & $\begin{array}{c}\text { Employ- } \\
\text { ment } \\
\text { cost } \\
\text { index }^{\mathrm{b}}\end{array}$ & $\begin{array}{l}\text { Major } \\
\text { union } \\
\text { agree- } \\
\text { ments }^{c}\end{array}$ & $\begin{array}{l}\text { Con- } \\
\text { sumer } \\
\text { price } \\
\text { index }^{\mathrm{d}}\end{array}$ & $\begin{array}{c}\text { Implicit } \\
\text { GNP } \\
\text { deflator }\end{array}$ & Civilian & $\begin{array}{l}\text { Men } \\
\text { aged } \\
24-54\end{array}$ \\
\hline $1965-69$ & 5.4 & n.a. & n.a. & 3.8 & 4.2 & 3.8 & 2.0 \\
\hline $1970-74$ & 7.2 & n.a. & 8.2 & 6.7 & 6.8 & 5.4 & 3.0 \\
\hline $1975-79$ & 7.7 & $7.6^{\mathrm{f}}$ & 8.4 & 8.2 & 7.6 & 7.0 & 4.4 \\
\hline 1980 & 9.3 & 9.0 & 9.9 & 12.5 & 9.9 & 7.1 & 5.2 \\
\hline 1981 & 8.1 & 8.8 & 9.5 & 8.9 & 8.7 & 7.6 & 5.5 \\
\hline 1982 & 6.1 & 6.3 & 6.8 & 3.8 & 5.2 & 9.7 & 8.0 \\
\hline 1983 & 3.8 & 5.0 & 4.0 & 3.8 & 3.6 & 9.6 & 8.2 \\
\hline 1984 & 3.2 & 4.1 & 3.7 & 3.9 & 3.4 & 7.5 & 5.9 \\
\hline 1985 & 3.2 & 4.1 & 3.3 & 3.8 & 3.1 & 7.2 & 5.6 \\
\hline 1986 & 2.0 & 3.1 & 2.3 & 1.1 & 2.2 & 7.0 & 5.6 \\
\hline 1987 & 2.6 & 3.3 & 3.1 & 4.4 & 3.3 & 6.2 & 5.0 \\
\hline
\end{tabular}

Source: Hourly earnings index, consumer prices, and unemployment rate are from U.S. Department of Labor, Bureau of Labor Statistics, Employment and Earnings, various issues. Employment cost index and major union agreements are from Bureau of Labor Statistics, Current Wage Developments, vol. 40 (March 1988). GNP deflator is from National Income and Product Accounts.

n.a. Not available.

a. December to December percent change for private nonagricultural workers.

b. December to December percent change of wages and salaries of private industry workers.

c. Average annual wage adjustment effective in the year for all industries. Major agreements are those covering 1,000 or more workers.

d. December to December percent change.

e. Fourth quarter to fourth quarter percent change.

f. $1976-79$.

been so slow. The trend is particularly striking because of the drop in unemployment, from 9.6 percent to 6.2 percent, between 1983 and 1987 .

\section{Aggregate Wage Growth}

To estimate the size of the unexpected component in the recent slowdown in wage growth, we fit a series of augmented Phillips curves, in which aggregate wage growth is modeled as a function of the unemployment rate and the expected rate of price inflation. Expected inflation is measured with a three-year distributed lag on the actual rate of inflation. The regressions explain annualized quarterly percentage changes in the average hourly earnings index (HEI) for the private nonfarm economy. We use changes in quarterly averages of unadjusted monthly 
HEI data to have available a full range of comparable data for the nine industrial divisions that underlie the aggregate index. Because we do not use seasonally adjusted data, we include additive quarterly dummy variables in each regression to control for seasonality.

Two specification issues are important: the unemployment variable and the variable to test for effects of international trade on wages. Because the demographic mix of unemployment has changed since the 1960s and 1970s, the choice of the cyclical control variable strongly influences the performance of the regressions. Associated with the high overall unemployment of the 1980 s has been a large component of longterm unemployment and of unusually high adult male unemployment. In every year between 1981 and 1987 the number of workers unemployed 27 weeks or longer exceeded 1 million, and the share of those workers in total unemployment was at least 14 percent. Between 1948 and 1979 long-term unemployment shares of 14 percent or higher occurred in just seven other years: 1958, 1959, 1961, 1962, 1975, 1976, and 1977. The exceptionally high adult male unemployment rate may be due to the increased pace of U.S. industrial restructuring and increased foreign trade competition as well as to the persistently high overall unemployment of the decade. In 1987, when the overall unemployment rate was 6.2 percent, the unemployment rate for men aged 25-54 was 5.0 percent, or 0.81 of the overall rate. In 1976, an earlier year when the unemployment rate for men aged 25-54 was 5.0 percent, the overall rate was 7.7 percent. Figure 1 illustrates this relative change in adult male unemployment of the 1980s. The relative unemployment rate for men aged 25-54 averaged 0.79 between 1980 and 1987 , but 0.59 in the 1970 s.

The change in the structure of relative unemployment rates makes the choice of which unemployment rate series to use in the regressions particularly important. ${ }^{1}$ We use both the overall unemployment rate and the rate for men aged 25 to 54 . Equations based on the unemployment rate for adult men predict lower wage growth for the 1980s.

Given the long-run trend toward increased openness of the U.S.

1. The importance of changes in the demographic structure of unemployment and its implications for labor market inflation were first emphasized by George L. Perry, “Changing Labor Markets and Inflation," BPEA, 3:1970, pp. 411-41. For a recent analysis of demographic changes in the unemployment of the 1980s, see Lawrence H. Summers, "Why Is the Unemployment Rate So Very High near Full Employment?" BPEA, 2:1986, pp. 339-83. 
Figure 1. Ratio of Unemployment Rates for Men Aged 25-54 to the Civilian Unemployment Rate, 1953:1-1987:4

Ratio

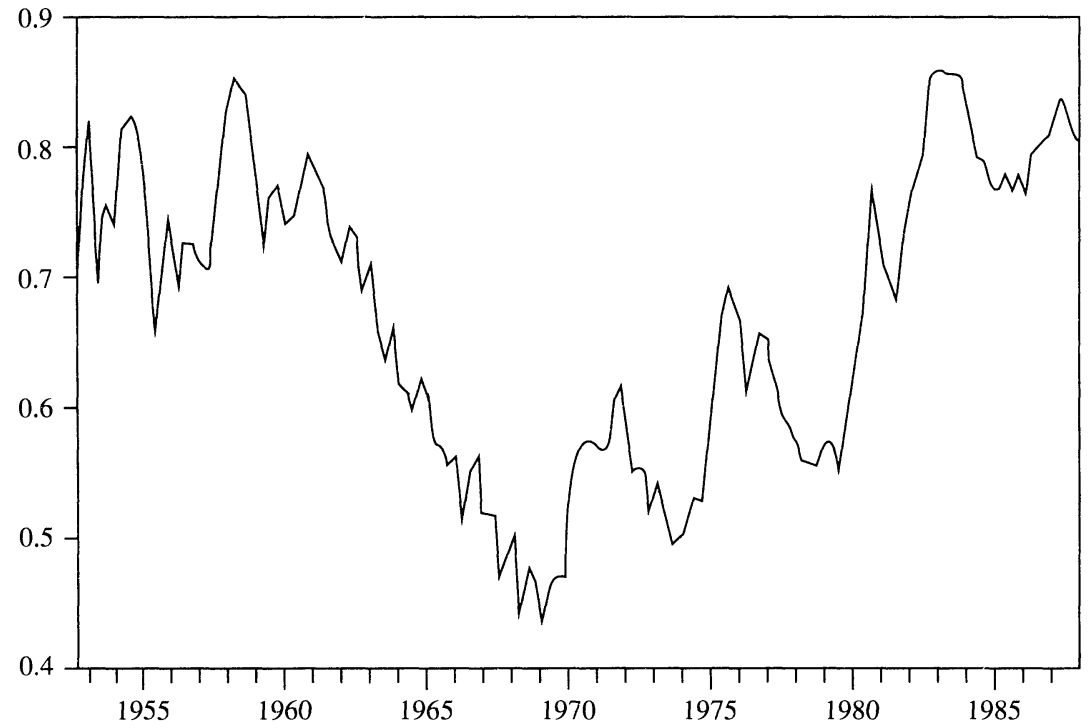

Source: Employment and Earnings, various issues.

economy and the persistence of large U.S. merchandise trade deficits since 1984, we test for the effect of foreign trade on domestic wage growth, using both price variables and trade flow variables. ${ }^{2}$ Price variables include changes in import prices and changes in nominal and real exchange rates. ${ }^{3}$ Trade flow variables include imports as a share of GDP or of sales, as well as export shares and net export shares. We find that import price inflation exhibits consistently small but significantly

2. John M. Abowd codirected a recent large-scale project at the National Bureau of Economic Research that assessed the effects on the labor market of international trade and immigration. In a later section of this paper we use international trade data and equation specifications drawn partly from that project in a microeconomic analysis of union wage settlements in manufacturing. See John Abowd and Richard Freeman, "The Internationalization of the U.S. Labor Market" (National Bureau of Economic Research, March 1987).

3. Rudiger Dornbusch and Stanley Fischer, "The Open Economy: Implications for Monetary Policy and Fiscal Policy," Working Paper 1422 (NBER, August 1984); Robert J. Gordon, "U.S. Inflation, Labor's Share and the Natural Rate of Unemployment," paper presented at International Seminar on Recent Developments in Wage Determination, Mannheim, Germany (October 5-6, 1987). 
positive effects on the growth in private nonfarm hourly earnings. Import price inflation net of petroleum and petroleum products has coefficients ranging from 0.08 to 0.14 in aggregate equations. Expected negative effects of changes in the trade-weighted real or nominal U.S. dollar exchange rate are not significant. Also insignificant are the potential positive effects of the export share and the net export share (as a percentage of real GDP) and an expected negative effect of the import share. As will be reported later, import shares are significant in an analysis of microeconomic data from manufacturing. We attribute the contrast in results to the greater range of variation of import shares in the microeconomic data.

Table 2 shows a set of six regression results and equation projections for 1980-87. Price inflation is measured with the consumer price index, entered as a twelve-quarter distributed Almon lag starting with a onequarter lag. Import price inflation, measured with a fixed-weight index of nonpetroleum import prices from the national income accounts, enters as an Almon variable with a four-quarter lag. The data period for all regressions begins in 1964:2 and ends in either 1979:4 or 1987:4.

The first two equations in table 2 show the importance of the choice of unemployment measure. In augmented Phillips curves fitted through 1979:4, unemployment and lagged inflation are both significant, with the inflation rate the more significant of the two. Equation 2, which uses the unemployment rate for men aged 25-54, fits somewhat better over the sample period and makes much more accurate wage growth projections for 1980-87. The average overprediction errors over the eight-year projection period are, respectively, 1.50 percent and 0.49 percent. When import price inflation is added, in equation 3, the average eight-year projection error drops to 0.02 percent. The addition of import prices causes the equation to make lower wage growth projections from 1981 through 1985. As the average projection errors in table 2 show, the use of the unemployment rate for men 25-54 causes about two-thirds of the difference between the projections made by equations 1 and 3 in the $1980 \mathrm{~s} .^{4}$

4. A similar decomposition between the average errors from equations 1 and 3 was obtained when import price inflation was added to equation 1 . In a regression that used import price inflation and the unemployment rate for persons aged 16 and older, the average overprediction errors for 1980-87 and 1984-87 were, respectively, 0.88 percent and 1.11 percent. Thus under both possible decompositions, the use of the unemployment rate for men aged 25-54 made a larger contribution than import price inflation to the superior performance of the projections from equation 3 compared with equation 1 . 
Table 2. Regressions Explaining the Growth in the Hourly Earnings Index, 1964:2-1979:4 and 1964:2-1987:4 a

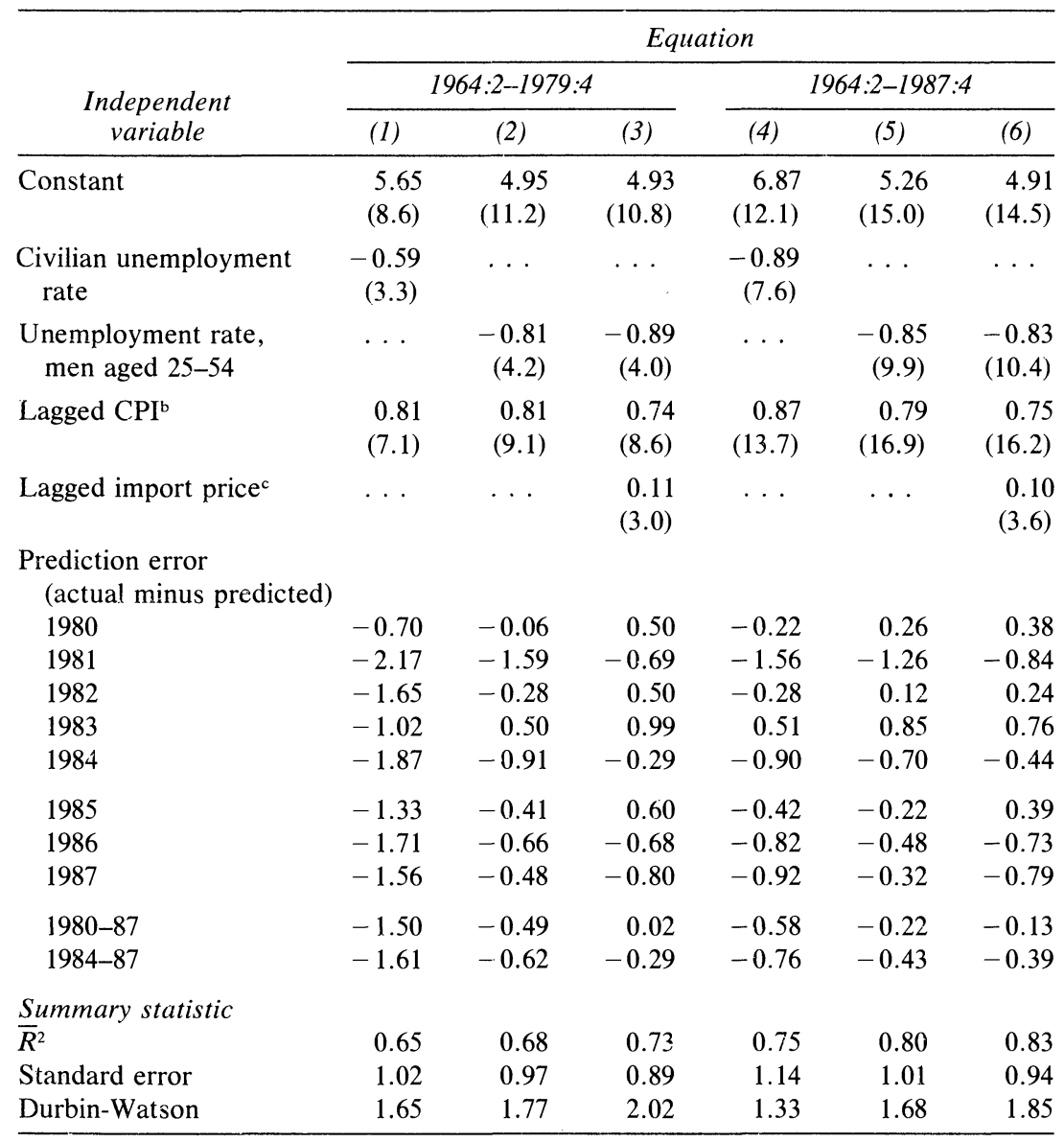

Source: Authors' calculations based on data from the Bureau of Labor Statistics and the National Income and Product Accounts.

a. The dependent variable measures the annualized quarterly percent change in the average hourly earnings index Data are not seasonally adjusted, and each regression includes quarterly seasonal dummies. Numbers in parentheses are $t$-statistics.

b. Lagged one quarter. The variable enters as an Almon variabie with a 12-quarter distributed lag.

c. Fixed-weight index of nonpetroleum import prices. The variable enters as an Almon variable with a four-quarter lag.

Equations 4-6 apply the specifications of equations 1-3 to the full period 1964:2 through 1987:4. Equations 5 and 6 are similar to equations 2 and 3 in both their coefficients and average projection errors. In equation 4 the average projection errors of the 1980s are reduced, compared with those of equation 1 , because these later observations help to determine the estimated coefficients. Although the average 
residuals in the 1980s are generally smaller in equations 4-6, the rank ordering across the three equations is generally preserved-that is, those from equation 4 are the largest. All equations overpredict in 1986 and 1987. Import price inflation of these years adds to the overpredictions.

\section{Wage Adjustments in Broad Industrial Divisions}

As a check on our aggregate wage change equations, we next conduct disaggregated analysis on the nine broad industrial divisions that make up the hourly earnings index. As table 3 shows, the divisions have wide variation in the demographic mix of employment, the degree of openness to international trade, and the extent of unionization.

In general, the industrial divisions in which men aged $25-54$ constitute a large share of total employment are also comparatively open to trade and have above-average unionization. Mining and durable manufacturing, for example, rank high on all three dimensions, while retail trade, finance, and services rank low on all three. The other four industry divisions are more mixed, with the two biggest exceptions being wholesale trade, which has more adult male employees than might be expected, and construction, which is less open to international trade than might be expected.

Because demographic mix, openness to international trade, and unionization have common patterns across broad industrial divisions, an analysis of wage dynamics at this level of disaggregation is less revealing than might be expected. In a longer, unpublished version of this paper, we report wage growth regression results for the nine industries using the same specification as in the aggregate analysis of table 2. While interesting in several respects, the results for the nonpetroleum import price inflation variable were not consistent across industrial divisions. Specifically, wage growth in wholesale and retail trade showed more sensitivity to international trade than was plausible given these industries' tenuous connection to the international economy.

To help isolate the separate effects of demographics, international trade, and union wage developments, we conduct two additional analyses. First, we examine union wage adjustments from the manufacturing sector, using detailed international trade data by industry to explore both trade and demographic effects on union wage adjustments. Second, we examine major collective bargaining agreements in the 1980s. 
Table 3. Demographic, International Trade, and Unionization Characteristics of Major Industrial Divisions

\begin{tabular}{lcccc}
\hline \multicolumn{1}{c}{ Industry } & $\begin{array}{c}\text { Employ- } \\
\text { ment share } \\
\text { ofmen aged } \\
25-54, \\
1980\end{array}$ & $\begin{array}{c}\text { Export } \\
\text { employ- } \\
\text { ment share } \\
\text { gained, } \\
1984^{\mathrm{a}}\end{array}$ & $\begin{array}{c}\text { Import em- } \\
\text { ployment } \\
\text { share lost, } \\
1984^{\mathrm{b}}\end{array}$ & $\begin{array}{c}\text { Union rep- } \\
\text { resentation } \\
\text { share, } \\
1987\end{array}$ \\
\hline Mining & 0.606 & 0.245 & 0.460 & 0.195 \\
Construction & 0.604 & 0.016 & 0.022 & 0.222 \\
Durable manufacturing & 0.505 & 0.154 & 0.254 & 0.263 \\
Nondurable manufacturing & 0.400 & 0.093 & 0.251 & 0.224 \\
Transportation and utilities & 0.546 & 0.101 & 0.076 & 0.362 \\
Wholesale trade & 0.481 & $0.060^{\mathrm{c}}$ & $0.014^{\mathrm{c}}$ & 0.091 \\
Retail trade & 0.243 & $0.060^{\mathrm{c}}$ & $0.014^{\mathrm{c}}$ & 0.074 \\
Finance & 0.286 & 0.026 & 0.027 & 0.032 \\
Services & 0.253 & 0.025 & 0.023 & 0.076 \\
All industries & 0.372 & 0.065 & 0.078 & 0.146 \\
\hline
\end{tabular}

Sources: Employment shares for men aged 25-54 taken from U.S. Bureau of the Census, Census of Population 1980, Detailed Population Characteristics, U.S. Summary, Sec. A: United States (Government Printing Office, 1980). Export employment shares taken from Kan Young, Ann Lawson, and Jennifer Duncan, "Trade Ripples Across U.S. Industries" (U.S. Department of Commerce, January 1986), tables 3A, 3B, and appendix table 4B. Union representation data from Employment and Earnings, vol. 35 (January 1988).

a. Share of industry's total employment gained from export activity.

b. Share of industry's total employment lost due to import activity.

c. Average shares for wholesale trade and retail trade combined.

\section{Major Manufacturing Settlements}

In this section we disaggregate further and examine data from major manufacturing collective bargaining agreements between January 1959 and December 1984. Our goal is to quantify the determinants of nominal wages at the bargaining unit level. Using the estimated wage settlement equation, we show that settlements from 1980 through 1984 were predicted well by the same determinants that explained wages in the preceding two decades.

We also examine the extent to which wage settlements are influenced by changing import and export competition in the industry. Because manufacturing industries differ in their sensitivity to import competition, we simulated our estimated equation for each major industry group to study the effects of a permanent increase in the rate of imports on wage settlements.

The dependent variable is the annualized rate of wage growth over the life of the collective bargaining agreement. This rate includes wage changes effective on the day of settlement, scheduled deferred increases, 
and realized contingent cost-of-living adjustments (COLAs). The wage settlements are dated from the beginning of the new contract so that, for example, the wage growth dated 1984 covers $1984-86$ for a three-year collective bargain.

We consider three distinct types of explanatory variables in the wage settlement equations-aggregate labor market conditions, aggregate price inflation expectations and realizations, and industry-level product market conditions. We discuss each below.

The labor market controls are the adult male unemployment rate the month before settlement, the change in that rate since the last contract settlement (annualized), and the most recent wage settlement in either the automobile or steel industry (annual rate). The adult male unemployment rate is most naturally viewed as an indicator of the general tightness of the labor market. One expects the current wage settlement to be inversely related to the unemployment rate. The most recent nominal wage settlement in the automobile or steel industry is a well-known leading indicator of the new wage settlements in general. If it is providing information that augments the information in the prevailing price inflation expectations, it should be positively related to wage settlements.

We use two different measures of the expected inflation rate. The first is based on the predicted annual rate of change in the CPI as determined by the most recent annual rate of change and two annual lags. The expected inflation rate is calculated from the regression:

(1) $\ln C P I(t+12)-\ln C P I(t)$

$$
\begin{aligned}
= & 0.913+0.855[\ln C P I(t)-\ln C P I(t-12)] \\
& (4.847)(19.516) \\
& -0.375[\ln C P I(t-12)-\ln C P I(t-24)] \\
& (7.329) \\
& +0.307[\ln C P I(t-24)-\ln C P I(t-36)] \\
& (7.994)
\end{aligned}
$$

Period: January $1950-$ July $1986 ; \bar{R}^{2}=0.58$; Durbin-Watson $=0.085$.

Since we require a forecast of the annual inflation rate based upon inflation during the previous contract, this specification is the natural extension of the distributed lag specifications we fit to the quarterly data for the aggregate equations. The CPI-based expected inflation rate is 
calculated as the predicted annual inflation rate from this regression in the month before the contract was settled. The CPI-based inflation surprise is calculated as the realized inflation rate during the life of the contract (annual rate) minus the CPI-based expected inflation rate the month before the contract was settled.

Our second measure of expected inflation, the Livingston expected inflation rate, is the consensus expected annual inflation rate from the Livingston survey just prior to the contract settlement. ${ }^{5}$ The Livingston inflation surprise is calculated as the realized inflation during the life of the contract (annual rate) minus the Livingston expected inflation rate the month before the contract was settled. We also considered an expected inflation rate and inflation surprise based on the Survey of Consumer Finances, but the results did not differ substantially from those obtained with the other two measures and are not reported here.

The inflation surprise over the life of the current contract is relevant only for contracts that contain a contingent COLA clause. Because of the effects of triggers (minimum changes in the CPI required to produce an adjustment), such clauses typically increase realized wages more when the inflation surprise is positive. For this reason we allowed the inflation surprise to enter separately for positive and negative surprises. Only the positive inflation surprises over the life of the contract had consistently large effects. The inflation surprise affects wage growth more in contracts that do not cap the COLA formula than in contracts that cap the cost-of-living adjustment at a specified amount regardless of the level of inflation. For this reason we estimate the effects of the inflation surprise separately for capped and uncapped COLA contracts, and we suppress the current inflation surprise for contracts that do not include a COLA.

The effects of lagged inflation surprises are called "catch-up" effects. Wage catch-up occurs when the previous wage settlement was based on an inflation expectation that turned out to be substantially in error. This error is measured by the lagged inflation surprise (the difference between the realized inflation rate over the life of the previous contract and the inflation rate expectation the month before that contract was settled).

5. The Livingston survey, conducted by J. A. Livingston each June and December, surveys 60 economists from banking, labor, government, and universities regarding their predictions for various leading economic indicators. Survey results are maintained by the Philadelphia Federal Reserve Bank, Department of Research. 
The effects of catch-up are symmetric, so no distinction is required for positive and negative surprises. However, catch-up should be a less important phenomenon for contracts with uncapped COLA clauses. We estimate separate catch-up terms for the cases in which the previous contract contained no COLA, an uncapped COLA, and a capped COLA.

Finally, we consider two types of product market controls. The first is the annual rate of change in industry prices as measured by the value of product shipments deflator from the Annual Survey of Manufactures (ASM). The second product market measure is a decomposition of the ASM value of shipments into the weighted sum of the annual rate of change in apparent domestic consumption $(D)$, defined as shipments $(S)$ plus imports $(M)$ minus exports $(X)$; the annual rate of change in exports; and the absolute change in $I P R$, the import penetration ratio (100 times imports divided by apparent domestic consumption). The decomposition of product shipments is given by:

$$
d \ln S=\frac{(S-X)}{S} d \ln D+\frac{X}{S} d \ln X-\frac{D}{S} d I P R,
$$

and all changes have been multiplied by 100 . This decomposition allows us to measure the effects of increased import and export activity in the product market holding constant total apparent domestic consumption. ${ }^{6}$ In particular, if the absolute value of the effect of the import penetration ratio on wage settlements exceeds the absolute value of the effect of apparent domestic consumption, then import competition has a greater effect on wage settlements than just the effect implied by the reduction in domestic output that accompanies an increase in the $I P R$ with industry prices and domestic consumption held constant.

To complete our dynamic specification, we also include the nominal wage settlement from the previous contract and the annual rate of change of bargaining unit employment over the life of the previous contract as control variables in our estimated equation. ${ }^{7}$

Table 4 compares alternative specifications of the dynamic model for

6. This decomposition is discussed and used in Richard B. Freeman and Lawrence Katz, "Wages and Employment in an Open Economy," prepared for the NBER conference on Immigration, Trade, and Labor Markets (September 1987).

7. John M. Abowd and Thomas Lemieux, "The Effects of International Trade on Collective Bargaining Agreements: Evidence from Canada," prepared for the NBER Conference on Immigration, Trade, and Labor Markets (revised January 1988). 


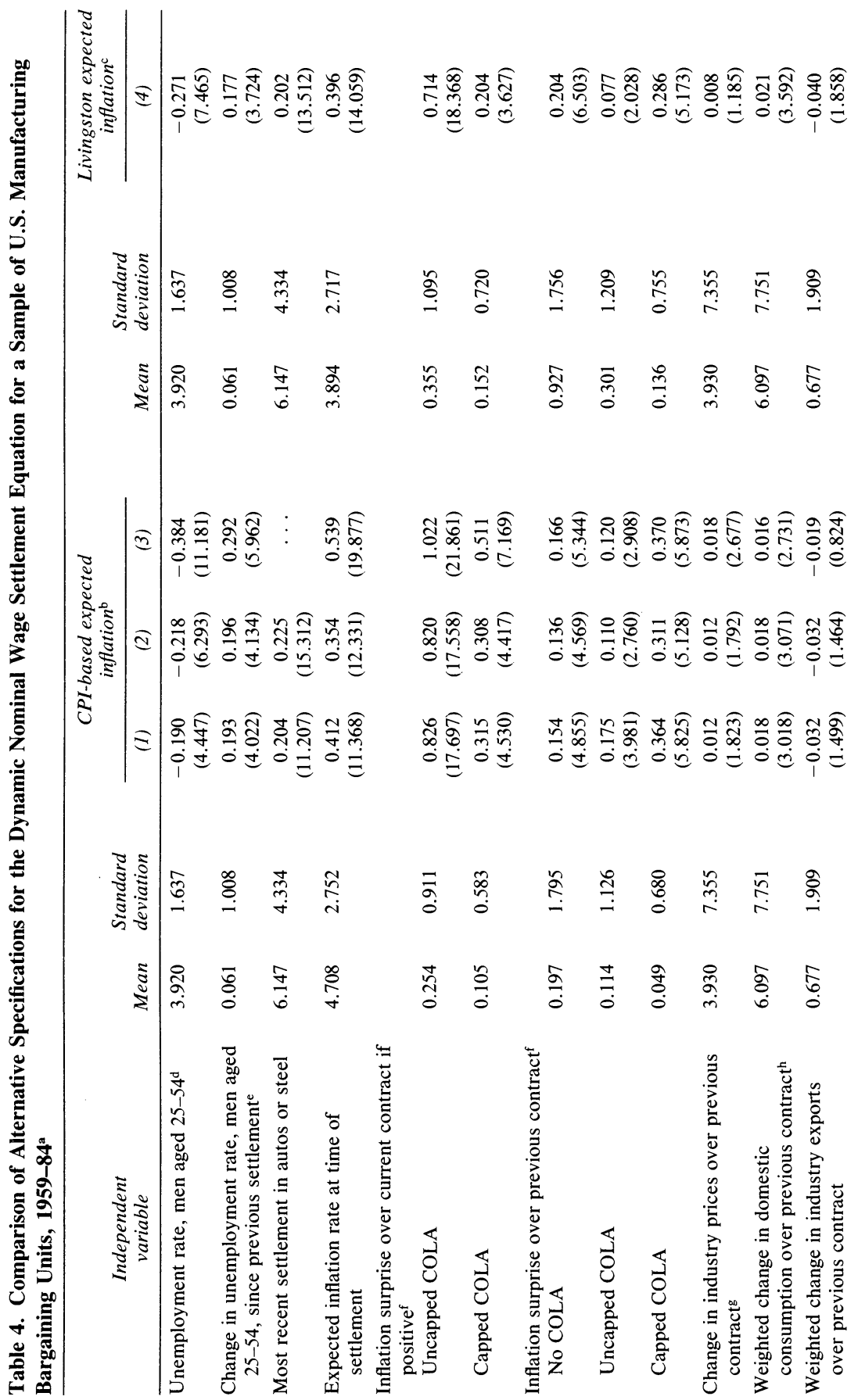




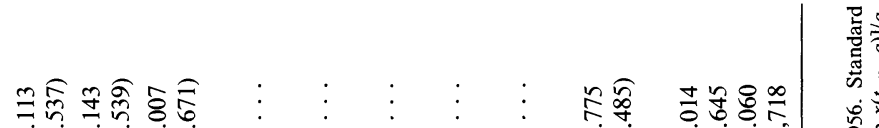

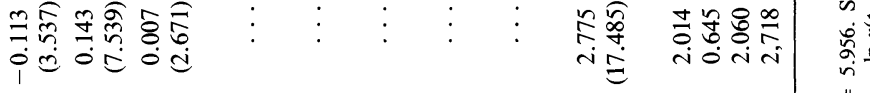

$\frac{1}{10}$

"I

₹高

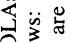

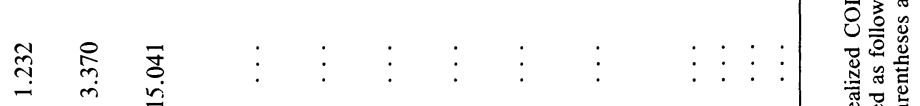

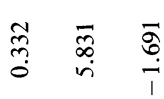

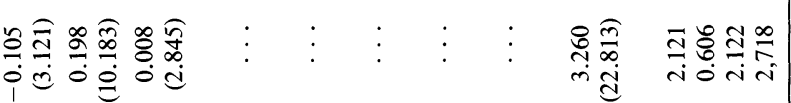

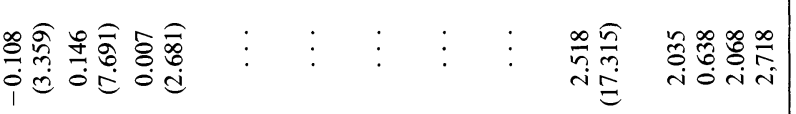

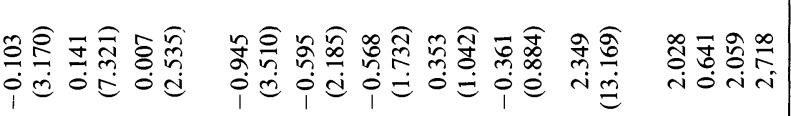

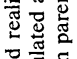

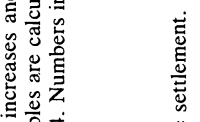

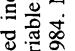

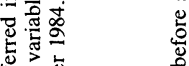

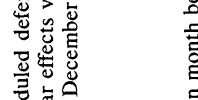

焉

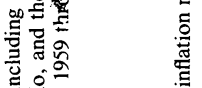

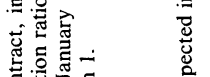

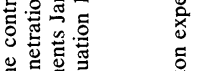

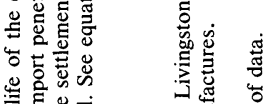

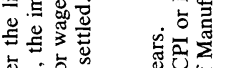

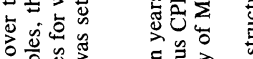

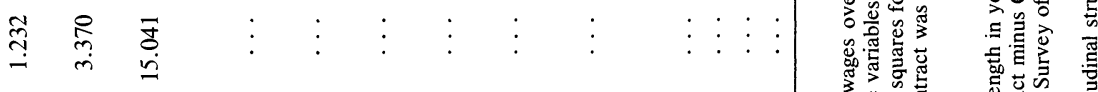

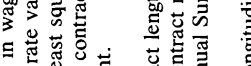

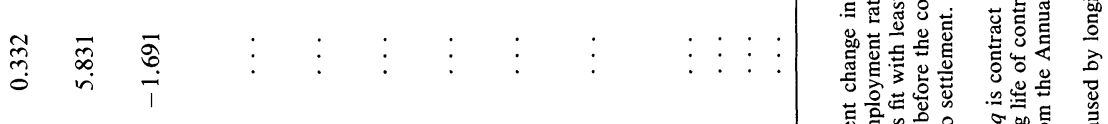

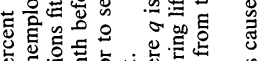

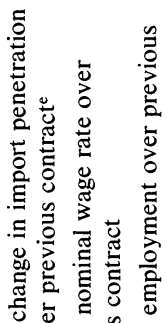

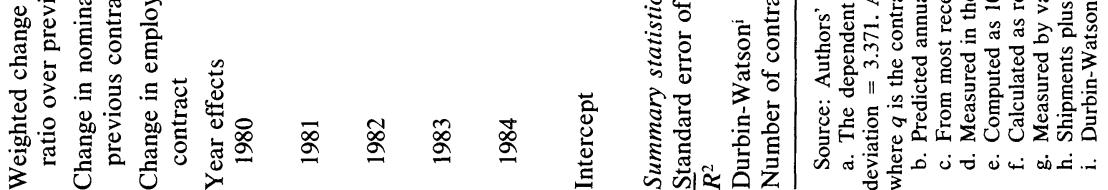

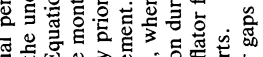

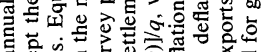

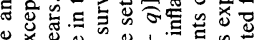

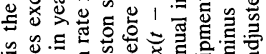

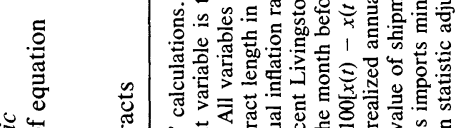

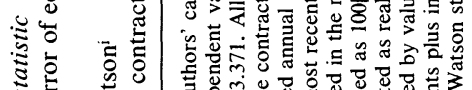

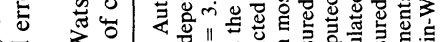

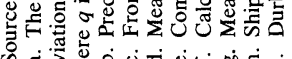


wage settlements estimated for 1959-84. Columns 1-4 report regression coefficients and their associated $t$-statistics, with columns 1-3 using the CPI-based measure of expected inflation and column 4 using the Livingston expected measure.

The first question of interest is the extent to which the period from 1980 through 1984 represents a break from the structure of wage determination in the previous two decades. Column 1 reports the regression estimates of the dynamic wage settlement equation from a specification that includes year effects (dummies) for each year from 1980 to 1984 . These year effects show that the equation overpredicts wage settlements in four of the five years, although only the 1980 and 1981 overpredictions are statistically significant. The relevant standard for interpreting these year effects as forecast errors is the standard error of the equation, which is 2.028; hence, none of the errors in the 1980s exceeds one-half of the standard error of the equation. Although overprediction if 1980 is large, it is about the same as overpredictions in $1960,1969,1970$, and 1971. The errors in 1981-84 are about the same as those of the previous decades. The equation with the Livingston measure of expected inflation reaches a similar conclusion.

Figure 2 breaks the predicted wage settlements into five key components. Not shown is a sixth component, average annual effect of changes in industry conditions including imports, discussed below, that contributes an average of 88 basis points a year and explains about 50 basis points of the decline in the 1980s. The figure shows that from 1980 through 1984 nominal wage settlements declined about 600 basis points. Of that total the decline in expected inflation contributed about 200 basis points; the decline in key settlements in the automobile and steel industries contributed another 200 basis points; positive inflation surprises contributed nothing; catch-up (lagged inflation surprises) contributed about 100 basis points; and the level and change in adult male unemployment contributed about 50 basis points.

The next question of interest is the extent to which the decomposition of the aggregate factors affecting the wage settlements is sensitive to the choice of expected inflation rate measure or the use of the key auto and steel settlement variable. Table 4 reports results in column 4 for the Livingston expected inflation rate measure. The equation based on the Livingston expected inflation rate fits the data slightly better than the equation based on the CPI expected inflation rate (column 2). The only 
Figure 2. Components of Predicted Wage Settlement, 1959-84

\section{Percent}

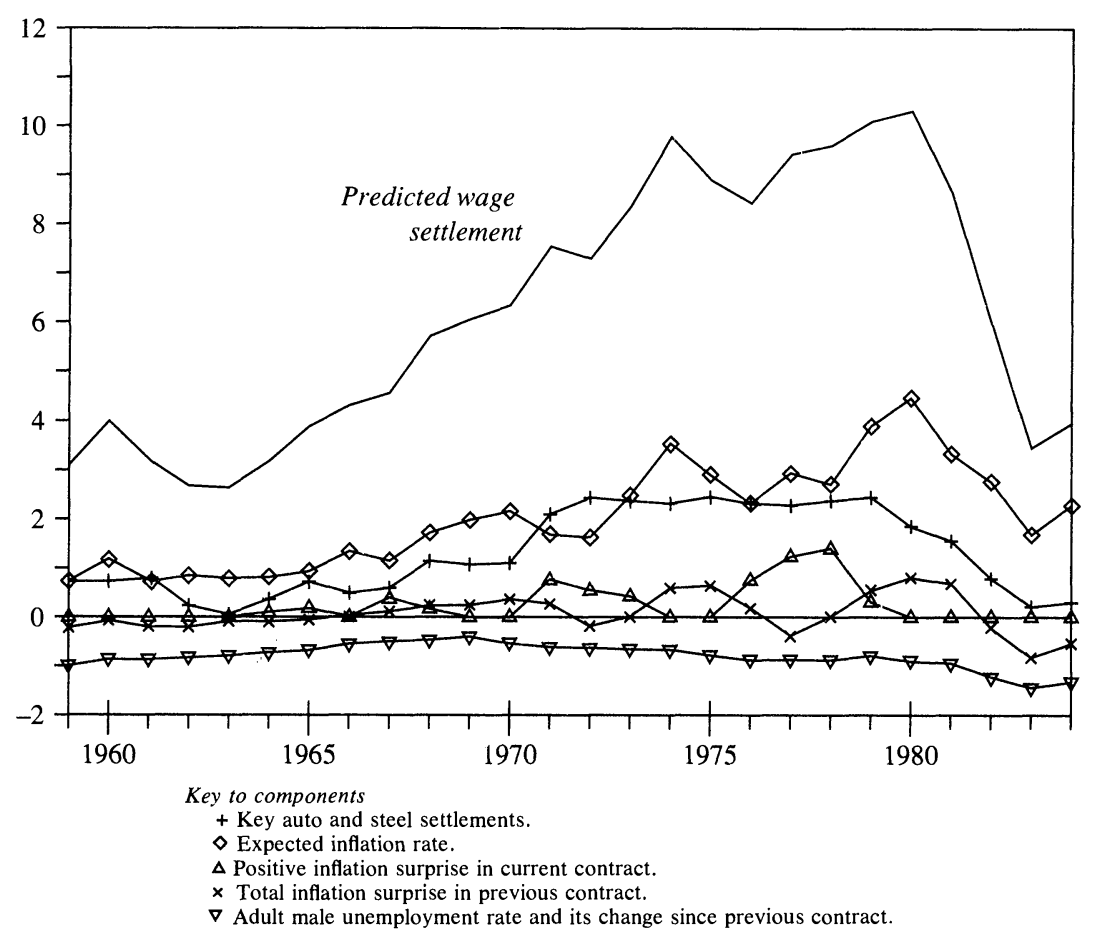

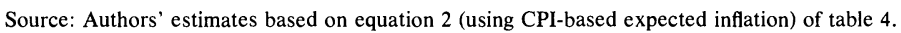

estimated effects that are materially different are the lagged inflation surprise terms. With the CPI-based measure, the estimated catch-up for contracts with no COLA is smaller than the catch-up for capped COLA contracts. With the Livingston measure, there is no significant difference between the no-COLA and the capped-COLA catch-up estimated elasticities.

Columns 2 and 3 of table 4 provide comparable estimates with and without the key settlements variable. The expected inflation rate elasticity in column 3 about equals the sum of the key settlement and expected inflation elasticities in column 2 . The positive inflation surprise elasticities in column 4 are greater than those in column 2, and the catch-up effects are also slightly larger. The effects of the level and change in the adult male unemployment rate are also larger in column 3 than in column 


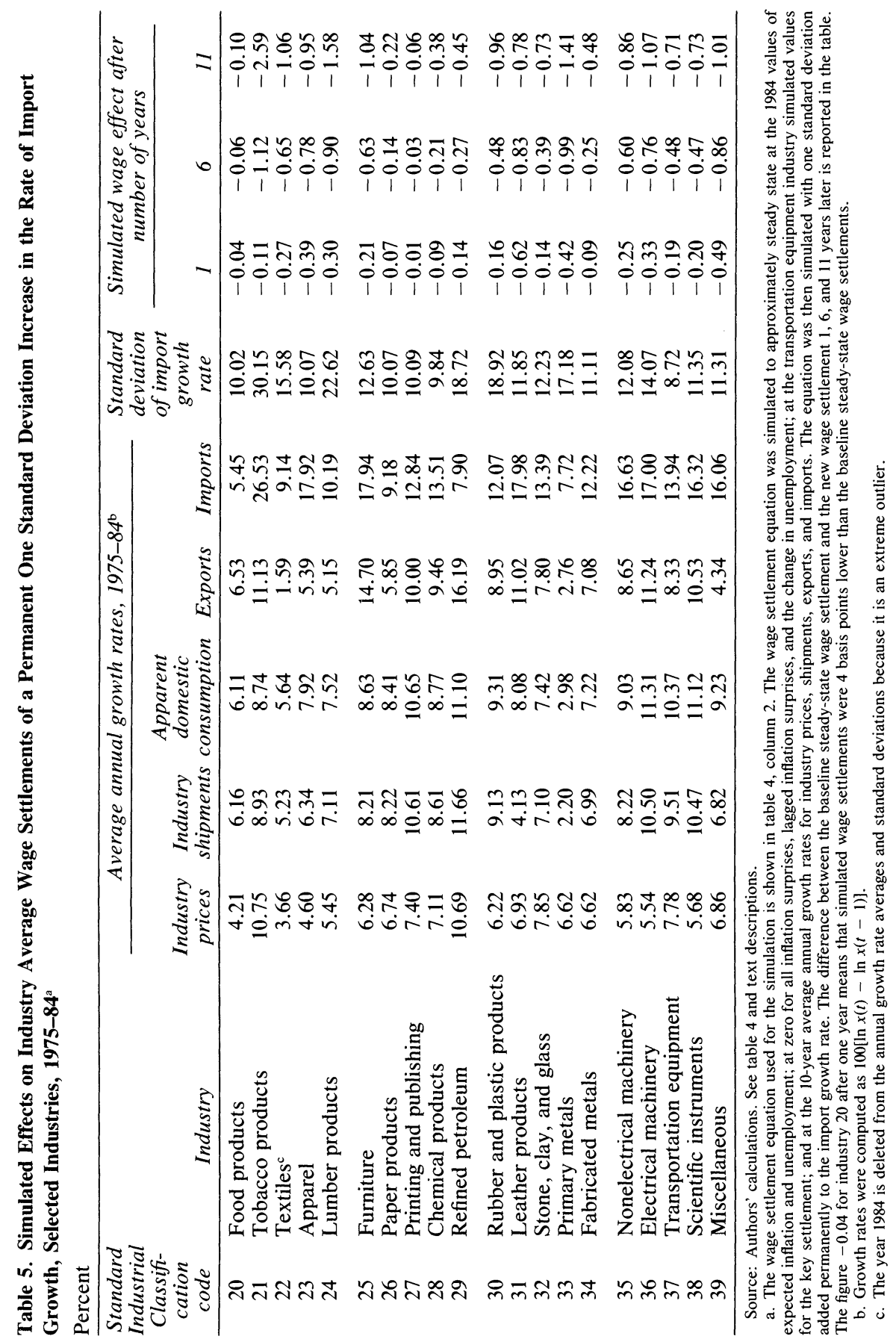


2. However, the equation in column 3 fits the data substantially worse than that in column 2. (The $F$-statistic for the significance of the change in $\bar{R}^{2}$ is 234.46 , which is the square of the $t$-statistic on key settlements in column 2.)

The final question of interest is the extent to which changes in the product markets, particularly changes related to import activity, affect wage settlements. As noted above, the cumulative contribution of all product market factors to the decline in wage settlements during the early 1980s was about 50 basis points. This estimate masks considerable heterogeneity among industry groups. As is clear from the estimated effect of changes in import penetration on nominal wage settlements for all of the models in table 4, the coefficient is six times greater than the coefficient on the change in apparent domestic consumption. In other words, the effect of import penetration on nominal wage settlements is approximately six times greater than one would predict from the lost domestic output alone.

Table 5, which shows the effects on wage settlements of increasing imports, reports the results of simulating the equation in table 4 , column 3, separately for 20 two-digit Standard Industrial Classification (SIC) code industries. Each settlement is first simulated to approximate steady state, using the 1984 values of expected inflation, unemployment, changes in the nominal wage over the previous contract, and change in employment over the previous contract. The 1984 positive inflation surprises, lagged inflation surprises, and change in adult male unemployment are entered as initial conditions, then zeroed to obtain the steady state. Finally, the 10-year industry average annual growth rates for prices, shipments, exports, and imports are used to generate the simulation values for the change in industry prices, apparent domestic consumption, exports, and the import penetration ratio. We simulated the transportation equipment industry first and used lagged values of the predicted settlements in this industry as the key settlement variable in the steady-state simulation.

Once the industry is in steady state (approximately 10 years into the simulation), the rate of growth of imports is permanently increased by one standard deviation for each industry. The table reports the resulting differences in predicted wage settlements in that industry for the first, sixth, and eleventh years following this change. The simulation holds constant the growth rate of industry prices, shipments, and exports, so 
there is no change in the rate of growth of real domestic production. The entire change is in the rate of growth of apparent domestic consumption and in the import penetration ratio. The simulated wage settlement effects, then, may be interpreted as the net effects of increased foreign product market share holding constant the rate of growth of real domestic shipments.

Wage increases in all industries are slowed by the increased growth of imports. The leather products, primary metals, and apparel industries have the largest predicted effects in the first year of the simulation. The largest long-term effects occurred in the tobacco products, lumber products, and primary metals industries.

The results using microeconomic data contrast with the aggregate results mentioned earlier. With microeconomic data the effect of expected inflation is only 0.54 when the key settlements variable is omitted, ranging up to 0.61 if one thinks that expected inflation is measured by adding its own coefficient and the coefficient on key settlements when they are entered together. By comparison, the elasticities from the macroeconomic results in table 2 range from 0.74 to 0.87 . The larger expected inflation coefficients in table 2 probably mean that these price terms are incorporating catch-up as well as expectational effects on nominal wage adjustments. The effects of unemployment are also smaller in the microeconomic data where both level and rate-of-change effects are identified. Together, their coefficients imply that it is lagged unemployment that affects current wage settlements. Separate product market and labor market effects on wage settlements are successfully isolated in the microeconomic data. In both the microeconomic and macroeconomic data, the effects of international trade appear to operate through imports but not exports and to moderate wage inflation in the $1980 \mathrm{~s}$. Aggregate data show that wages are affected by import prices. Disaggregated data show wages affected by the import penetration ratio.

\section{Union Wage Settlements}

During the 1980s wage growth has slowed more in union bargaining situations than elsewhere in the private sector. Possible explanations include changes in unemployment demographics, international trade, and other competitive factors. In traded goods industries in which union workers are paid more per hour than nonunion workers, increased 
Table 6. Average Annual Rates of Wage Growth, Selected Periods, 1964-87 ${ }^{\text {a }}$

Percent per year

\begin{tabular}{|c|c|c|c|c|c|}
\hline \multirow[b]{2}{*}{ Period } & \multicolumn{2}{|c|}{ Hourly earnings index } & \multicolumn{2}{|c|}{ Employment cost index ${ }^{\mathrm{b}}$} & \multirow{2}{*}{$\begin{array}{c}\text { Major } \\
\text { union } \\
\text { agreements }\end{array}$} \\
\hline & $\begin{array}{l}\begin{array}{l}\text { High-union } \\
\text { industries }^{\mathrm{c}}\end{array} \\
\end{array}$ & $\begin{array}{l}\text { Low-union } \\
\text { industries }^{\mathrm{d}}\end{array}$ & $\begin{array}{c}\text { Union } \\
\text { workers }\end{array}$ & $\begin{array}{c}\text { Nonunion } \\
\text { workers }\end{array}$ & \\
\hline $1964-69$ & 5.1 & 5.7 & n.a. & n.a. & n.a. \\
\hline $1970-75$ & 7.6 & 6.7 & n.a. & n.a. & 8.3 \\
\hline $1976-82$ & 8.1 & 7.7 & 8.6 & 7.4 & 8.5 \\
\hline $1983-87$ & 2.5 & 3.0 & 2.8 & 4.0 & 3.3 \\
\hline
\end{tabular}

Source: Based on data from Current Wage Developments, various issues.

n.a. Not available.

a. December to December rates of growth.

b. Indexes for wages and salaries.

c. Weighted average of hourly earnings indexes for mining, construction, manufacturing, and transportation and utilities based on each industry's percentage of hours in 1967 .

d. Weighted average of hourly earnings indexes for wholesale, retail, finance, and services.

import competition could have adverse effects on both employment and wages for union workers. This section examines overall union wages and employment with attention to developments in the 1980s. Before discussing the 1980s, however, we briefly review earlier union-nonunion wage trends.

Because comprehensive time series data distinguishing union from nonunion wage growth became available only with the advent of the employment cost index in 1975, inferences for earlier periods must compare hourly earnings growth in industries with high unionization rates with that in industries with low unionization rates. In an examination of the growth in average hourly earnings among private nonfarm three-digit industries between 1953 and 1976, Dan Mitchell found that hourly earnings in highly unionized industries grew more rapidly than those in low-unionization industries between 1953 and 1958 and again between 1971 and $1976 .{ }^{8}$ During 1971-76 the wage growth differential favored high-union industries by about 1 percentage point a year. By contrast, between 1964 and 1968, hourly earnings grew more rapidly in industries with low unionization rates.

Table 6, which shows average annual rates of wage growth for selected periods for three wage series, confirms Mitchell's findings. The hourly earnings index data show that wages grew more rapidly in low-union industries in the late 1960s and again during 1983-87, while the converse held during 1970-75 and 1976-82. Over the entire 1964-87 period,

8. See Daniel J. B. Mitchell, Unions, Wages, and Inflation (Brookings, 1980), chap. 2, pp. 23-61. 


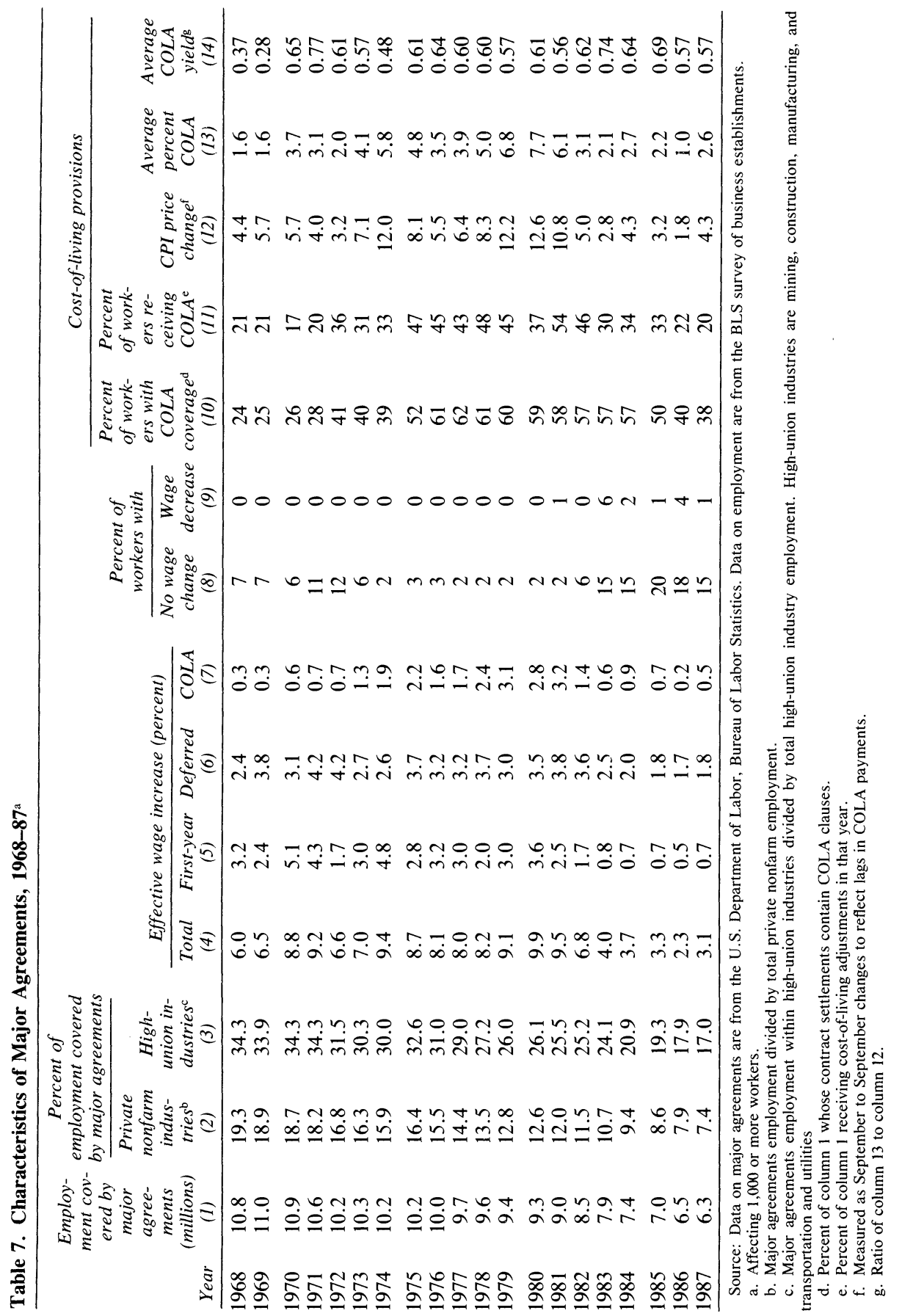


however, average annual wage growth was about the same (5.7 percent) in low- and high-union industries. The explicit union-nonunion comparison using employment cost index data shows a 1 percentage point differential in favor of union workers during 1976-82 (8.4 percent, as against 7.4 percent), but then a 1 percentage point lower rate of union wage growth during 1983-87 (3.3 percent, as against 4.3 percent). The wage deceleration since 1983 has been 2 percentage points larger for union workers than for nonunion workers (5.1 points, as against 3.1 points). Table 6 also shows the similarity of union wage increases in the employment cost index and the effective wage changes in major union agreements (those affecting 1,000 or more workers). The simple correlation of the two annual wage change series from 1976 to 1987 is 0.990 .

Workers covered by major agreements constitute more than half of all union workers in the private nonfarm economy. Although the ECI has wage change data for all union workers, the major union agreements data have some important advantages for present purposes. They go back to 1968 for all private industries and include detail not available in the ECI data: effective wage changes broken down by source (currentyear negotiations or first-year increases, deferred increases from prior settlements, and cost-of-living increases), the number of workers receiving each type of wage change, and the coverage of COLA clauses.

Table 7 summarizes information on employment and effective wage changes in major agreements since 1968. One important feature of the data is the decline in the number of workers covered by these agreements, as shown in column 1-from 10.8 million workers in 1968, to 9.7 million in 1977 , to only 6.3 million in 1987. Employment covered by major agreements fell from 19.3 percent to 7.4 percent of private nonfarm wage and salary employment during these 20 years. The decline in the employment share parallels the general decline in private sector unionization. For 1973-81 and 1983-87, the years when comparisons with Current Population Survey (CPS)-based unionization estimates can be made, the two series move almost identically. The major settlements employment shares of column 2 averaged 62.8 percent of the CPS unionization rate estimates, and their time series correlation was 0.973 .

About 85 percent of workers covered by major agreements work in the highly unionized mining, construction, manufacturing, and transportation and utilities industries, industries whose share of private wage and salary employment shrank from 50.0 percent in 1968 to 35.6 percent 
in 1987. The changing mix of employment by industry thus also affects the major agreements employment share in column 2. Column 3, however, shows that the share of employment covered by major agreements in the highly unionized industries declined from 34.3 percent to 17.0 percent between 1968 and 1987. Because major agreements employment has declined relative to total employment in all private industries, most of the decline in the share of overall employment shown in column 2 has been due to developments within industries and not to changes in the industry mix of employment. The employment percentage in column 2 for 1987 would have been 9.5 percent, rather than 7.4 percent, if the highly unionized industries had retained their 1968 share of total private nonfarm employment.

The first three columns of table 7 suggest that the decline in major agreements employment was more rapid in the late 1970s and 1980s than in earlier years. The explanation for the decrease in the employment base for major agreements, and for private sector union employment in general, includes regional employment relocation toward less unionized states in the Sun Belt; changes in the industrial relations practices of employers, particularly large employers, toward unions; reduced union organizing activity and lower success rate in representation elections; changes in worker attitudes toward unions; deregulation in the transportation and communication industries; and increased import competition. ${ }^{9}$ The increase in the union wage premium implied by the union and nonunion wage growth trends during 1970-82 probably gave employers increased financial incentives to use nonunion workers. Table 7 shows that even after the economy emerged from the 1981-82 recession, the employment base for the major agreements continued to decline, from 7.9 million workers in 1983 to 6.3 million in 1987.

To explain the decline in employment covered by major agreements we fit time series and cross-section regressions. Both regression analyses include controls for the effects of international trade. Time series variation in the major agreements employment percentage within the highly unionized industries $(P)$, column 3 of table 7 , is explained with

9. For analyses of the decline in private sector unionization, see William T. Dickens and Jonathan S. Leonard, "Accounting for the Decline in Union Membership, 19501980," Industrial and Labor Relations Review, vol. 38 (April 1985), pp. 323-34; and Henry S. Farber, "The Decline of Unionization in the United States: What Can Be Learned from Recent Experience?'” Working Paper 2267 (NBER, May 1987). 
regressions that also include controls for the business cycle (URM, the unemployment rate for men aged 25-54), the regional mix of employment in these industries (EMIX, employment in the Northeast and Midwest as a percentage of national employment), and a control for the accelerated downward trend that started in 1976 (T76). The international trade variable in the time series analysis is real imports measured as a percentage of real $\operatorname{GDP}(R M S)$. The regression shown below, with $t$-statistics in parentheses, explains 99.1 percent of variation in the employment percentage during 1968-87.

$$
\begin{gathered}
P=\begin{array}{c}
\text { (0.4) } \\
(0.7)
\end{array} \quad 0.564 U R M+0.598 E M I X-0.540 T 76-0.991 R M S \\
\bar{R}^{2}=0.991 ; \text { standard error }=0.51 ; \text { Durbin-Watson }=1.45 .
\end{gathered}
$$

All four explanatory variables are statistically significant. In recessions, major agreements employment declines more slowly than overall employment in the highly unionized industries, perhaps because workers are still covered by the agreements even if they are not all employed. The downward trend in the major settlements employment percentage is explained by regional employment mix, the trend acceleration after 1976 , and growth in the real import share. Because the real import share grew from 7.9 percent of real GDP in 1968 to 14.8 percent in 1987, the equation implies that growth in international trade accounted for 41 percent of the total decline in the major agreements employment percentage.

The cross-section analysis examines the change in the major agreements employment share between 1978 and 1987 at the level of two-digit SIC industries. For 36 private nonfarm industries in which major agreements covered at least 5 percent of industry employment in 1978, the major agreements employment share was lower in all but one industry (SIC 24, lumber) in 1987. To explain the decline, we fit regressions that include the level or the change in import-related employment losses between 1977 and 1984..$^{10}$ Also included are controls for industry employment growth and a dummy variable for three industries with major

10. Kan Young, Ann Lawson, and Jennifer Duncan, "Trade Ripples Across U.S. Industries"' (U.S. Department of Commerce, January 1986). 
regulatory changes (trucking, airlines, and communications). Employment growth and deregulation do not add significantly to explained variation in this analysis. The simple regressions that use, respectively, the average level and the change in import-related employment losses are as follows:

$$
\begin{gathered}
D P=-\begin{array}{c}
33.86-0.30 \text { A VIMP } \\
(88.3) \quad(2.0)
\end{array} \\
\bar{R}^{2}=0.081 ; \text { standard error }=18.31, \\
D P=-\begin{array}{cc}
36.42 & -0.324 \text { DIMP } \\
(10.1) \quad(1.7)
\end{array} \\
\bar{R}^{2}=0.048 ; \text { standard error }=18.65 .
\end{gathered}
$$

In the regressions the variables are measured as follows:

$D P=$ the percentage change between 1978 and 1987 in major agreements employment as a percent of total industry employment

MEL77 = employment losses due to imports in 1977 measured as a percent of domestic employment in the industry in 1977

MEL84 = employment losses due to imports in 1984 measured as a percent of domestic employment in the industry in 1984

AVIMP $=$ average employment loss due to imports between 1977 and $1984=(M E L 77+$ MEL84 $) / 2$

$D I M P=$ difference in employment loss due to imports between 1977 and $1984=$ MEL84 - MEL77.

The cross-section regressions allow for changes in import penetration by industry in ways not permitted in a more aggregate analysis. Both import variables have negative coefficients as expected, but note the size and significance of the intercepts. The regressions suggest that import penetration accounted for 10-20 percent of the employment losses between 1978 and 1987 experienced by workers covered by major agreements. Taken together the time series and cross-section results imply that international trade has contributed to the employment losses in major agreements, but that other factors combined have had quantitatively larger effects.

The steady decline in membership and in the size of bargaining units has undoubtedly influenced union objectives in collective bargaining. 
Greater job security has become such an important objective in the $1980 \mathrm{~s}$ that unions have been willing to trade away wage increases to get it. The 1980s have seen the spread of so-called concession bargains whose wage provisions include freezes and reductions, an increased prevalence of lump sum payments, and two-tier pay arrangements. Coincident with these changes in contractual wage provisions have been sharp reductions in work stoppages.

Table 7 displays selected indicators of increased union willingness to forgo wage increases in recent years. All three components of effective wage increases (columns 5, 6, and 7) declined sharply between 1981 and 1983 and remained low through 1987. From 1983 through 1987 the total annual effective wage change was below 4 percent, and first-year and COLA increases remained below 1 percent a year. Columns 8 and 9 show that union willingness to accept wage freezes and wage reductions increased sharply during 1983-87, contributing to the smaller observed first-year wage increases. In any one year in this five-year period about one-fifth of workers received no wage increase. In the decade 1973 to 1982 , that proportion reached as high as 6 percent only twice.

Union bargainers have also been willing to give up cost-of-living escalators in recent years. Following nearly a decade (1976 to 1984) when COLA coverage averaged about 60 percent, coverage declined to 50 percent in 1985 and then to roughly 40 percent in 1986 and 1987 . Of workers with COLA coverage, the proportion who actually receive COLAs, the ratio of column 11 to column 10, dropped noticeably during 1983-87, averaging 0.76 between 1976 and 1982 but only 0.57 from 1983 through 1987. The decline in the importance of COLAs as a component of union wage changes has been due to three factors identifiable in table 7: the low inflation rate of 1983-87 (column 12), the decline in COLA coverage (column 10), and the decline in the proportion of those covered who actually receive COLAs (column 11 as a fraction of column 10).

The full extent of the union wage deceleration and the component parts of the deceleration are clearly illustrated by the data in columns 4-7 of table 7. First-year adjustments and COLA increases have both been especially small during 1983-87.

The explanation for the deceleration of union wage gains, both absolutely and relative to nonunion gains, could be international trade. At least four considerations, however, suggest that other factors are important as well. First, the accelerated decline in the employment base for the major agreements, and for union employment more generally, 
predates by at least seven years the emergence of the large U.S. merchandise trade deficits in 1984. Second, domestic economic developments are capable of explaining why recent union wage increases have been unusually small. In both the time series and the cross-section analysis of major settlements employment shares, we find that international trade is important but does not account for the majority of the employment losses. The growth of nonunion employment, deregulation in the transportation and communication industries, the development of dual union-nonunion industrial relations strategies among large employers, and worsening worker attitudes toward unions have all contributed to hard times for unions. ${ }^{11}$ The emergence of a substantial merchandise trade deficit has contributed to the decline in unionized employment, but so have all these other developments. Third, our analysis of microeconomic data from manufacturing does not suggest that international trade is the main cause for smaller union settlements in the 1980s. Fourth, an analysis by Mitchell concludes that international trade and deregulation have not been the root cause for the large increase in concession bargaining since $1982 .{ }^{12} \mathrm{He}$ finds that in industries not directly affected by trade or deregulation, union wage concessions have been at least as prevalent and as large as elsewhere.

The preceding suggests continuing moderation in union wage demands. The short-term prospect for union employment is for further reductions, both generally and in the major bargaining situations. With a declining employment base, union negotiators will continue to focus on job security and downplay wage demands.

In summary, the slowdown in wage inflation of the 1980s is due not only to reduced inflationary expectations, but to the increase in relative unemployment among adult men, the decline in union wage settlements, and the competitive effects of imported goods and services. Because these developments are likely to persist, they point to continued modest wage growth for the rest of 1988 and into 1989.

11. The changing environment of industrial relations is documented in Thomas A. Kochan, Harry C. Katz, and Robert B. McKersie, The Transformation of American Industrial Relations (Basic Books, 1986). One analysis of changes in worker attitudes toward unions is found in Farber, "The Decline in Unionization." His analysis suggests that nonunion workers became less favorably inclined toward unions between 1977 and 1984.

12. See Daniel J. B. Mitchell, "Wage Trends and Wage Concessions: Implications for Medium Term Economic Expansion," Working Paper 114 (Institute for Industrial Relations, University of California at Los Angeles, July 1986). 


\section{Comments and Discussion}

Gary Burtless: Wayne Vroman and John Abowd have written a rather discursive paper on three aspects of recent wage inflation: the changing demographic profile of unemployment and its effect on wage pressure in labor markets, the impact of international trade on wage bargains, and the declining role of unions in aggregate wage determination. In my comments, I shall focus on the regression results discussed in the first two-thirds of the paper.

The authors begin by analyzing aggregate wage inflation, as measured by the hourly earnings index. The econometric specification and results of this analysis are shown in table 2 . The Phillips curves estimated in the table are based on an extremely parsimonious specification. The equations include only the level of the unemployment rate and the lagged value of price inflation. The authors argue-and I certainly agree-that the unemployment rate of men between the ages of 25 and 54 is a more reliable indicator of labor market tightness than the overall unemployment rate. The results in table 2 suggest that a 1 percentage point rise in male unemployment is associated with a drop in nominal wage inflation of $0.8-0.9$ percent.

The specification of the effects of price inflation will raise a few eyebrows. In the simplest equation, Vroman and Abowd include the distributed lagged rate of change in the consumer price index over the previous three years. The coefficients on this variable imply that within three years of a jump in prices, hourly earnings rise enough to offset about 80 percent of the price hike. When the authors want to juice up this parsimonious specification, they add the four-quarter distributed lag of import price inflation (excluding petroleum).

Under one interpretation of this procedure, the authors are trying to capture the impact of greater or lesser price competition in product markets on the pace of domestic wage increases. If import prices fall 
relative to domestic prices, wages will be held down in the domestic sectors that compete with imported goods. The estimated coefficient, which significantly improves the fit of the equation, especially in recent years, appears to confirm this hypothesis.

One might think that this kind of product-market pressure would grow as the share of imported goods in the U.S. market rises. In the mid1960s, U.S. imports were less than 5 percent of GNP; today, they are around 11-12 percent. So one would anticipate that the effect of import price movements on U.S. wages would be greater today than in the 1960 s. Perhaps this is the reason that the regressions in table 2 consistently overpredict aggregate wage inflation in recent years, even when they include the term measuring import price inflation. Note, however, that the error in prediction is consistently smaller in the equations that include import price changes than in those that exclude this term.

Although the effect of trade on the overall U.S. economy may be growing, the effect on average wage bargains may be declining. My impression is that goods-producing industries that are heavily involved in trade account for a declining fraction of U.S. employment. So while the effect of trade on these sectors may be rising, the importance of the wage settlements struck in these sectors is probably shrinking.

It would be reasonable to expect that import price movements should have the greatest influence in sectors that directly compete with imported goods-namely, the goods-producing industries, excluding construction. But such was not the pattern discovered by the authors in sectoral regressions that are mentioned, though not presented, in this paper. In those sectoral regressions the authors found that wage increases in mining and durable and nondurable manufacturing are significantly affected by import prices. That is, wages in those sectors are restrained if overall import prices decline or grow slowly. But the authors also found that wages in transportation and in retail and wholesale trade are just as strongly influenced by import price movements as wages in the goods industries. Why should this be the case when workers in these service industries do not directly compete with imported services?

Part of the problem is that relevant import price pressures are poorly measured by the regressor included in table 2 and in the sectoral regressions mentioned in the text. In principle, the authors should include a variable that captures import prices of goods and services that compete directly with those of the affected industry. Overall import price movements might do a bad job. 
Vroman and Abowd address this issue in the most novel part of their paper-the section dealing with collective bargaining settlements in manufacturing. Here their data set includes detailed information about trade pressure within specific industrial product lines. Before developing this point, though, I should briefly describe the data set, which, as just mentioned, pertains to union settlements in manufacturing.

It is unfortunate that manufacturing employment is a declining portion of all U.S. employment. And it is still more unfortunate that collective bargaining covers a steadily dwindling share of workers, even in manufacturing. These things are not necessarily unfortunate in themselves, either for the economy or for workers-although there are still a few of us who think so. They are unfortunate from the point of view of analysts who take a great interest in collective bargaining arrangements within manufacturing. However intriguing these arrangements are, their relevance to general wage patterns is receding.

But I have come to praise this data set, not to bury it. The authors have collected in one place a truly astonishing file of information about collective bargaining agreements in manufacturing. The file covers a 26year span from 1959 through 1984, and includes information on more than 2,700 individual agreements. The data have been organized in such a way that the analyst can derive the implications of an individual contract for wage changes in each year covered by the contract, including the effect, if any, of the COLA clause. What is more, the authors have tabulated detailed information about the specific manufacturing industries represented in the file, including such data as the level of industry shipments, imports, exports, domestic consumption, and price changes. Consequently, the regressions reported in table 4 are estimated with a huge cross-sectional time series data set, packed with detailed information that is generally believed relevant to wage settlements.

Veteran macroeconometricians might be astonished at the number of observations used to estimate the equations. As a microeconometrician myself, I am less easily impressed. Articles in leading microeconomic journals often contain as many or more observations. The many available observations here present some problems of interpretation to macroeconomists accustomed to dealing with compact data sets. Given enough observations, one could enter "Number of Light-years to the Dog Star" as a right-hand-side variable and get a "significant" coefficient. A coefficient that is statistically significant is not necessarily practically significant, in the sense that it has a meaningfully large effect on the 
dependent variable. On the other hand, a very low $t$-statistic is informative. If a variable is reasonably well identified in the data-and I would expect all of Vroman and Abowd's are-an insignificant coefficient does not mean "undecided," as it might in smaller data sets. It means "This variable is unimportant." Even at the outer bounds of the 95 percent confidence interval, the variable has no meaningful effect on the dependent variable.

The specification used by Vroman and Abowd in table 4 includes the prime-age male unemployment rate, anticipated inflation at the time of the contract settlement (measured two different ways), the "inflationary surprise" over the life of the contract (relevant mainly for wage bargains containing a COLA clause), and several measures of demand for the industry's product line. This last set of variables is a clever decomposition of demand changes into product price changes, changes in domestic shipments, changes in exported shipments, and changes in the share of imports in domestic consumption. The last variable-changes in the import penetration ratio-is clearly included to capture the effects of import pressures on wage settlements.

What should we conclude from the results in table 4? First, the male unemployment rate has a remarkably small, although statistically significant, effect on wage settlements. If I read the results correctly, the effect is only a small fraction of that implied in the aggregate regressions reported in table 2 .

Second, wage earners obtain a substantially smaller share of price increases than is suggested in table 2, where the aggregate equations showed that wages eventually rose by $75-80$ percent of the change in the CPI. The results in table 4 suggest that on average workers might get only one-third to two-thirds of the price rise, with workers covered by COLA clauses getting the most and workers not covered by COLAs getting the least.

Third, wages appear to be relatively insensitive to demand conditions in product markets. Although the coefficients are often significant, as I just noted, small coefficients can be statistically significant in large samples without any practical significance for the dependent variable. Even under the highest estimate of wage rate sensitivity, for example, a 10 percentage point rise in industry product prices leads to only a 0.2 percent hike in negotiated wages.

The notable exception to this generalization appears to be imported 
goods competition, although even here the simulation results reported in table 5 suggest that the cumulative effect of imports is small. Import penetration has a significant, but not especially large, effect in restraining wages.

Fourth, in a nod toward institutional theories of wage bargaining, the authors include a variable reflecting the wage gain in the most recent auto or steel settlement. This variable is always found to have a large and reliably estimated effect on new wage bargains. Without quibbling with the institutional knowledge lying behind this specification choice, I think the inclusion of the steel and auto settlement variable is probably a bad idea.

Presumably, the most recent steel and auto wage increase already reflects the influence of some or all of the factors in the specificationthe current unemployment rate, expected inflation, general inflation in product prices, and so on. Hence, part of the effects of these variables is being captured by the coefficient on the auto and steel settlement, leaving the reader with no idea of the net equilibrium impact of, say, a change in unemployment on new wage settlements.

Of course, even with the current specification these effects could be derived using appropriate simulations. But the authors do not provide these, so the reader is left in the dark.

Even though I have emphasized the differences between the Phillips curves implied by the manufacturing regressions, on the one hand, and the aggregate equations, on the other, I think it important to note an interesting similarity. Nearly all of the recent residuals in the regressions have been negative. The aggregate as well as the microeconomic equations tend to overpredict nominal wage gains in the past few years. Many of the errors are quite large, particularly in view of the slow pace of real wage movements-and even nominal wage movements-in the 1980s.

Finally, we should take note of the absence of any productivity term in the equations shown on table 4 . While this is customary in aggregate Phillips curve equations, it may not be as reasonable with this kind of data set.

If there is a sectoral slowdown in productivity growth, and if the equations reported in table 4 remain valid predictors of wage movements, the combined effect would be higher unemployment or higher inflation, or both. Unless workers obtain a rising share of value added, either overall inflation or joblessness must rise to slow down the rate of real 
wage increase. The estimated coefficient on the unemployment rate is quite low, so it would presumably take a large—and permanent—rise in unemployment to effect the required wage slowdown. An increase in general price inflation would accomplish the same result, because nominal wages apparently rise only a fraction of a point for each 1 percentage point rise in inflation.

Perhaps the specification in table 4 is generally correct. Neither workers nor employers pay any attention to productivity trends when striking wage bargains. But it is at least possible that some employers take account of worker productivity when making wage offers or accepting a union's counteroffer. This proposition could be examined in the authors' data set by including sectoral productivity movements in the specification. Even if the industry-level productivity data are bad, it may be easier to test the idea here than in a normal macroeconomic data set. I do think this data set offers some intriguing possibilities. The authors should be congratulated for assembling it and showing how it can be exploited in a macroeconomic context.

\section{General Discussion}

Several panelists suggested modifications in the authors' aggregate wage equations. Robert Gordon agreed with Burtless that the equations are overly parsimonious, and he suggested including several lags of the unemployment rate. He noted that in his own paper in this volume, rateof-change effects are important; without lags such effects are precluded and the coefficient on the unemployment rate may be biased. Gordon also suggested allowing lagged wages to compete with lagged prices. He argued that the price effects were likely to have varied during the period, as the use of indexed wage contracts increased markedly during the 1960 s and decreased in the 1980s; ideally a variable reflecting this difference in coverage would be used in the equations. Edmund Phelps noted that the price variable may be serving as a proxy for expected wage change. He suggested adding productivity growth to the wage equations as a variable indicating both the capacity of firms to pay higher wages and workers' real wage aspirations. Such a variable, he reasoned, might account for the slowdown of wage growth in the 1980s.

Gordon observed that wages are only half the story. The ultimate 
object is to understand how wages get translated into prices. The recent theoretical emphasis on price rigidity, for example in the paper by Ball, Mankiw, and Romer in this volume, has reopened the question of whether wages are important to prices in the short run-an issue, Gordon noted, that is ignored by Vroman and Abowd. He suggested that large swings in labor's share argue against a simple model in which prices are marked up over wages. The recent decline in labor's share is the counterpart of the recent overprediction of the wage equations. Gordon also noted that these movements in labor's share mirror movements in the ratio of the adult male unemployment rate to the total unemployment rate. $\mathrm{He}$ speculated that when adult males are doing relatively well, they bid up wages in general, resulting in an increase in labor's share. Vroman linked the reduction in labor's share to the decline in union jobs in manufacturing.

Robert Hall noted the existence of simultaneity bias in the microeconomic as well as in the macroeconomic wage equations. In the face of shocks to wages, the dependent variable would be expected to feed positively into contemporaneous price changes, causing an upward bias in that coefficient. Similarly, feedback from wage change to unemployment would be expected to bias the coefficient on unemployment toward zero. Finally, both of these effects would lead to an underestimate of the standard error of the equation. Because it neglects these feedbacks, Hall reasoned, the estimated response of wages to aggregate demand from this type of equation is misleading, and the implication that inflation changes do not originate with wages cannot be accepted.

Abowd acknowledged the possibility of bias for the macroeconomic variables but argued that the variation in many of the variables in the paper's microeconomic equations is primarily cross-sectional. He added that the estimated equations were properly specified wage models with serially uncorrelated errors. He reported that the results are similar even if annual dummy variables are included. For example, the effects of trade penetration and contract-specific inflation surprises are consistently estimated. However, Christopher Sims observed that biases could exist even for these variables; for example, trade penetration in a particular industry could result from wage shocks in that industry.

Charles Schultze noted that the coefficient on expected inflation in the microeconomic equations should vary depending on whether there is a COLA clause and on the type of COLA clause in the contract. $\mathrm{He}$ 
found it puzzling that the equations implied that contracts without COLAs had responded very differently than contracts with COLAs to the combined effects of past and expected price changes. Vroman replied that attempts to estimate separate expected inflation effects on different types of contracts had not indicated a significant difference.

Gordon conjectured that the price coefficient in the aggregate wage equations was less than unity-the value some theories would predictbecause the consumer price index substantially overestimated housing costs in 1980-81. Vroman replied that although the coefficients estimated using other price indexes were sometimes closer to unity, the recent overpredictions of the wage equations remained. 